\title{
Correction to: Calcareous nannofossil biostratigraphy of the Lower-Middle Pleistocene boundary of the GSSP, Chiba composite section in the Kokumoto Formation, Kazusa Group, central Japan, and implications for sea-surface environmental changes
}

\author{
Koji Kameo $^{1^{*}}$, Yoshimi Kubota ${ }^{2}$, Yuki Haneda ${ }^{3}$, Yusuke Suganuma ${ }^{4,5}$ and Makoto Okada ${ }^{6^{*}}$
}

Correction to: Prog Earth Planet Sci 7, 36 (2020)

https://doi.org/10.1186/s40645-020-00355-x

In the original publication of this article (Kameo et al. 2020), a reference article is missing in the reference list. The missing reference should be referenced at the location in the main body of the article below where "Hole U1427" is referred to.

Main Text:

Their occurrences suggest that the influence of coastal water near the coast of the Japanese islands may have increased along with the Kuroshio Current after the full interglacial during MIS 19. In Japan Sea, subtropical Tsushima Warm Current radiolarian species were rapidly decreased in Hole U1427 (Sagawa et al. 2018). Sagawa et al. (2018) suggested that shallowing the Tsushima strait due to lowering sea-level prevented the Tsushima Warm Current from flowing into Japan Sea after interglacial maxima.

\footnotetext{
The original article can be found online at https://doi.org/10.1186/s40645020-00355- $x$

* Correspondence: kameo@faculty.chiba-u.jp; kameo@faculty.chiba-u.jp 'Department of Earth Sciences, Faculty of Science, Chiba University, 1-33, Yayoi, Inage, Chiba, Chiba 263-8522, Japan

${ }^{6}$ Department of Earth Sciences, Ibaraki University, 2-2-1, Bunkyo, Mito, Ibaraki 310-8512, Japan

Full list of author information is available at the end of the article
}

The missing reference:

Sagawa T, Nagahashi Y, Satoguchi Y, Holbourn A, Itaki T, Gallagher SJ, Saavedra-Pellitero M, Ikehara K, Irino T, Tada R (2018) Integrated tephrostratigraphy and stable isotope stratigraphy in the Japan Sea and East China Sea using IODP Sites U1426, U1427, and U1429, Expedition 346 Asian Monsoon. Prog Earth Planet Sci 5:18. https://doi.org/10.1186/s40645018-0168-7

\begin{abstract}
Author details
${ }^{1}$ Department of Earth Sciences, Faculty of Science, Chiba University, 1-33, Yayoi, Inage, Chiba, Chiba 263-8522, Japan. ${ }^{2}$ Department of Geology and Paleontology, National Museum of Nature and Science, 4-1-1, Amakubo, Tsukuba, Ibaraki 305-0005, Japan. ${ }^{3}$ Geological Survey of Japan, National Institute of Advanced Industrial Science and Technology, 1-1-1 Central 7, Higashi, Tsukuba, Ibaraki 305-8567, Japan. ${ }^{4}$ National Institute of Polar Research, 10-3, Midori-cho, Tachikawa, Tokyo 190-8518, Japan. ${ }^{5}$ Department of Polar Science, School of Multidisciplinary Sciences, The Graduate University for Advanced Studies (SOKENDAI), 10-3, Midori-cho, Tachikawa, Tokyo 190-8518, Japan. ${ }^{6}$ Department of Earth Sciences, Ibaraki University, 2-2-1, Bunkyo, Mito, Ibaraki 310-8512, Japan.
\end{abstract}

Published online: 14 September 2020

References

Kameo K, Kubota Y, Haneda Y, Suganuma Y, Okada M (2020) Calcareous nannofossil biostratigraphy of the Lower-Middle Pleistocene boundary of the GSSP, Chiba composite section in the Kokumoto Formation, Kazusa
Springer Open

๑ The Author(s). 2020 Open Access This article is licensed under a Creative Commons Attribution 4.0 International License, which permits use, sharing, adaptation, distribution and reproduction in any medium or format, as long as you give appropriate credit to the original author(s) and the source, provide a link to the Creative Commons licence, and indicate if changes were made. The images or other third party material in this article are included in the article's Creative Commons licence, unless indicated otherwise in a credit line to the material. If material is not included in the article's Creative Commons licence and your intended use is not permitted by statutory regulation or exceeds the permitted use, you will need to obtain permission directly from the copyright holder. To view a copy of this licence, visit http://creativecommons.org/licenses/by/4.0/. 
Group, central Japan, and implications for sea-surface environmental changes. Prog Earth Planet Sci. 7:36. https://doi.org/10.1186/s40645-02000355-x

Sagawa T, Nagahashi Y, Satoguchi Y, Holbourn A, Itaki T, Gallagher SJ, SaavedraPellitero M, Ikehara K, Irino T, Tada R (2018) Integrated tephrostratigraphy and stable isotope stratigraphy in the Japan Sea and East China Sea using IODP Sites U1426, U1427, and U1429, Expedition 346 Asian Monsoon. Prog Earth Planet Sci 5:18. https://doi.org/10.1186/s40645-018-0168-7 